\title{
AN EXPLORATORY STUDY ON EFFICACY OF DEMONETIZATION IN INDIA: POLICY ROLLOUT ON DEMONETIZING OLD CURRENCY
}

\author{
Abdul Masood Panah \\ PhD Scholar \\ Department of Commerce \\ Mangalore University, Mangalagangothri \\ Mangalore, Karnataka, India, 574199 \\ E-mail: mazzpanah@gmail.com \\ Dr. Y. Muniraju \\ Professor \& Dean \\ Department of Commerce \\ Mangalore University, Mangalagangothri \\ Mangalore, Karnataka, India, 574199 \\ E-mail: drymuniraju97@gmail.com
}

\begin{abstract}
Demonetization is the process of declining the use of currency from circulation by the government or monetary authorities in a country. This research paper analyses the efficacy of Indian demonetization from common public perspectives, the policy that the government of India has implemented to fight against black money, drying the financial roots of terrorism, and direct the civilization towards digital transactions and a cashless economy. A field survey was conducted in Karnataka and Kerala's coastal region by distributing a structured questionnaire among the common public to generate the data. The authors run descriptive statistics and ordinal regression analysis to obtain the result for the study's objectives. The descriptive statistics result found that demonetization increased the number of bank account holders in India. There is not much impact of demonetization on controlling evasion of tax and illegal investments of black money, and the policy adversely affects regular business in the country. The findings from ordinal regression reveal that the time frame was given to the public to demonetize their old notes were sufficient; money circulation was well planned at the time of demonetization. The policy implemented at the right time and the common public, despite facing enormous challenges while purchasing goods and services at the time of demonetization, considers that demonetization implementation was effective.
\end{abstract}

Keywords: Demonetization, Common Public, Efficacy, Policy Implementation, Currency.

JEL Classification Codes: E5, E6, E7, E58, E60. 


\section{INTRODUCTION}

Money is an essential instrument in the economy. Money is influencing the output and employment by affecting the cost of goods and services. It is also controlling the aggregate flow of saving and investment (M C Vaish, 2005). The majority of the people worldwide use money daily to buy or sell goods and services, pay or get paid, or write or settle contracts. Notes are central to the workings of the modern economy (McLeay \& Radia, 2014). The central bank issue maintains the currency and is authorized to decline or ban the money from circulation in a country's economy (Khiaonarong \& Humphrey, 2019). Cash is the most extensively used payment instrument worldwide(Paul van der Knaap et al., 2018), but cash will no longer be king (Massi et al., 2019) as a large number of countries in the globeare trying to reduce the use of cash in their economies. Economies that are much cash-intensive tend to grow slowly and miss out on significant financial benefits.

Conversely, economies that switch to digital are much successful; the switch can boost economic growth by as much as three percentage points (Massi et al., 2019). Numerous countries attempted to digitalize their economies and people by demonetizing their currencies and overcoming hyper-inflation and also, getting rid of the defects of black money and counterfeit currency (Mahajan \& Singla, 2017; Chowdhury \& Hosain, 2018). Demonetization is the process of declining the use of money from circulation by the government or monetary authorities in a country (Ghosh et al., 2017). It is the process where governments are stripping a currency unit or the realmoney as a legal tender, usually by replacing it with a new currency (Panah \& Muniraju, 2020). Therefore, the common public cannot use the old money in their daily dealings for purchasing goods and services. India to fight black money, fake currency, which was a good source for terror groups, and also, to reduce the number of cash in circulation, which was directly related to corruption in the country, and to digitalize the economy demonetized $86 \%$ of the total currency in circulation on 8 November 2016 (Ghandy, 2016; Sivathanu, 2019). India's government has given the common public a limited period to bring their old notes and exchange them with the new currency (Beg \& Joshi, 2017). Therefore, this paper aims to study the common public's opinions on policy reactions, understand their hardships due to the notes' demonetization, and study whether the policy implementation was effective. The study results depict that demonetization increased the number of bank account holders in India. There is not much impact of demonetization on controlling evasion of tax and illegal investments of black money, and the policy adversely affects regular business in the country. Despite facing enormous challenges while purchasing goods and services at the time of demonetization, the common public considers that demonetization implementation was effective in India.

\section{LITERATURE REVIEW}

Demonetization is one of India's most memorable economic events that affect all citizens and the economy through the liquidity side. The objectives of the demonetization were annihilating black money, counterfeit currency, drying up the financial roots of terrorism, and direct the economy of the country and civilization toward cashless transactions and cashless economy (Briceno \& de Hurtado, 2019; Chodorow-Reich et al., 2020; Ghosh et al., 2017; Kumar, 2017; Mohan \& Ray, 2019; Sharma, 2019; Vij, 2018). Studied the impact of demonetization on the Indian economy (Briceno \& de Hurtado, 2019; Chodorow-Reich et al., 2020; Kumar, 2017), the results obtained from demonetization in India are a shortage of liquidity, changes in consumer preferences, increased inflation, decreased productive activities, the new distribution of monetary cone, and more significant electronic usage transfer and increased deposits, and decreased the banks' credit 
growth in India.(Mohan \& Ray, 2019; Sharma, 2019; Vij, 2018), the decision of demonetization shocked the economy for a while. It impacted the economy in various sectors. The size of black money reduced to $15 \%$ of official GDP, the GDP has been hampered. There was a positive impact of the demonetization on the CPI inflation rate as the rate dropped post demonetization. The exchange rate of foreign currencies has not been significantly impacted.(Ghosh et al., 2017), studied the impacts ofdemonetization on the economy, they mentioned that demonetization doesn't lead to a reduction in inflation as it can only be achieved through the recession; their book $(2017$, p15, 58, 64) discussed that demonetization resulted in the most significant adverse effect on the informal economy due to loss of liquidity, which drastically affected trading and supply chain across the country.(Dash, 2017; Lal, 2018; Samuel \& Saxena, 2017; Singh, 2018), Studied positive and negative impacts of demonetization. The demonetization shows a mixed effect on various issues; the shortage of cash creates hardships and challenges in the everyday living of the common public in short-rub, but its impact will defiantly prove positive in the longterm.(Beg \& Joshi, 2017; Dash, 2017; Koshy, 2017; Mahajan \& Singla, 2017; Mishra, 2017; Mohindra \& Mukherjee, 2018), studied the impact of demonetization on the common public. Their studies show thatdemonetization mainly impacted ordinary people rather than the people who are the main contributors to black money. Its impacts had a negative consequence on the poor. Indeed, the demonetization left many people with low access to cash in their daily lives. Different dimensions and effects of demonetization have been studied in the existing literature; this paper will address the efficacy of demonetization from common public perspectives on policy rollout demonetizing old currencies in India.

\section{Statement of Research Question}

Demonetization is not a recent phenomenon in India, and India has been implemented demonetization twice earlier. Suddenly, at midnight, November 2016, the government of India announced to the public that due to the existing large number of black money, destroying the financial resource of terrorist groups, and directing the country toward a digitalizedeconomy and a cashless society, the high-value currency which creates $86 \%$ of the total money in circulation will be no longer a legal tender and cannot be exchanged for purchasing goods and services until they replace it with the new currency in a short period. The next day, many of the common public rushed to the banks to exchange their old notes. ATMs had stopped working; the bank service rendered to people was not sufficient enough to reach all. The ordinary people were at the forefront of the government's decision to suffer from the harms of demonetization and shortage of liquidity in the country. Therefore, the scope of the efficacy of demonetization from the general public perspectives makes it more attractive to the researcher to study in-depth their opinions and reactions. On the other hand, it will add to the existing body of knowledge and act as a potential reference for policymakers for better future national policy implementation.

1) Did the policy rollout on demonetization effective?

2) Does demonetization help to achieve tax-compliance among citizens?

3) Does demonetization help in curbing the misuse of black money (Illegal activities)?

4) Does demonetization affect the SME's (petty business)

\section{Research Objectives}

- To study if the policy implementation was effective.

- To Study the opinions of the public on policy reaction

- To understand their hardships due to the implementation of the policy. 


\section{Research Limitation}

This study is limited to the common publicfrom the Coastal Region of Karnataka and Kerala.The researchers had faced a lack of understanding of local languages for interacting with the commonmasses and convincing them to respond to the questionnaire, lack of common public awareness about scientific research, and the researcher's vast challenges for conducting this research. Many times, the respondents were not ready to spare their time responding to the questionnaire.

\section{Research Delimitation}

Efficacy of demonetization in India; Policy rollout on demonetizing old currency is a fascinating topic and studied by conducting a survey between the general public inthe coastal region of Karnataka and Kerala states of India. The datasets were generated from the general public through sharing the questionnaires from August 2019 to November 2019.Section three of this study discusses the research methodology and section four represents the discussion of the results, and chapter five concludes the paper.

\section{RESEARCH METHOD}

\section{Population \& Sample}

The authors obtained the variables measured for this research model from a review of relevant literature.For this study, the respondents are the general public from the Coastal Region of Karnataka and Kerala.This study's source is from different groups; mostly, the researchers surveyed the people who do not have stable income such as, daily wage workers, agriculturalists, small business holders, retailers, and people who are part of the unorganized labor class. Nonprobabilistic convenient sampling technique was conducted. The nonprobability sampling technique is mainly used in surveys where the total population is unknown or cannot be individually identified(Chawla \& Sondhi, 2015; Kumar, 2011).

\section{Data \& Questionnaire}

The authors collected the respondent's responses to the pre-tested designed questionnaire. The questionnaire has been distributed between the common public in the coastal areas of Karnataka and Kerala. A total of 450 questionnaireswere printed and distributed among various groups of the respondents, and 274 respondents answered the survey questionnaire, of which 250 respondents considered appropriate responses for the study. The responses' internal consistency has been checked using Cronbach's alpha test and the scale items as 0.825 , indicating that the investigation is 82.5 percent reliable.

\section{Data Analysis}

The authorsanalyzed the common public reactionsto demonetization policy implementation by India's government using descriptive statistics. The researchers used ordinal regression analysis (ORA) to measure the common public's opinions on policy rollout on demonetizing old currency to understand its efficacy from the general public perspectives. The data on the government's appropriateness to demonetize the old money is considered as the response variable. And the money circulation planning,the time framegiven to the public to demonetize their old notes, public awareness on objectives of the policy rolled, the right time for demonetization implementation, facing problems while purchasing goods and services at the time of demonetization, lack of prior preparation, waiting in queues for exchanging old notes, and the 
quality service rendered by the banks are considered as covariates or explanatory variables. This is done to verify the common public reactions relating to the policy rollout's efficacy on demonetizing old currency matches and predicting the general public concerning the implemented policy's appropriateness.

Furthermore, the researchers consider the categorical measure of numerous age and professional groups as explanatory variables in the analysis to measure the policy appropriateness from different age and occupation groups' perspectives. The case processing summary of the categorical elements and the response variable is represented in table 01 . The authors classify the respondent's age into six alphabetic groups, group A. [25-30], and group B. [31-35], are the youngsters.Group C. [36-40], and group D. [41-45], represent middle-aged people. Group E. [46-50] and group F. [50 \&above] depict the veterans. Similarly, researchers categorize the occupational groups as daily wage workers, agriculturalists, small business holders, shopkeepers, and group 'others' representing the people from the unorganized labor class (housewives) and students.

The following equation signifies the general expression of our ordinal regression model.

$$
\operatorname{logit} Y_{i, j}=\alpha_{j}-\left\lfloor\sum_{i=1}^{n} \beta_{i} X_{1_{i}}+\sum_{t=1}^{p} Y_{i} X_{2_{i}}+\delta F+\varsigma B+\eta I+\lambda M+6 S+\theta T+\text { qL }+\mathrm{YY}+\varepsilon_{j}\right\rfloor
$$

Where, $Y_{i, j}$ is thecumulative probability of the $j^{\text {th }}$ category for the $i^{\text {th }}$ case; $\log i t Y_{i, j}$ is the $\log$ of an odds ratio $\left[\log \frac{\psi}{1-\psi} \mid\right.$ Where $\psi$ probability of the respondents in favor of demonetization. $\propto_{-} \mathrm{j}$ is the threshold/intercept value; $\mathrm{X}_{1}$ and $\mathrm{X}_{2}$ are factors in the ordinal regression model representing the categorical variables such as age and profession group, with $\beta$ and $\gamma$ coefficients, respectively; $n$ and $p$ indicate one less than the total number of categories in the age group and professional group, respectively. The variables F, B, I, M, S, T, L, and Y represent the model's covariates.Money circulation was well planned; the time framegiven to the public to demonetize their old notes, public awareness on objectives of the policy rolled, the right time for demonetization implementation facing problems while purchasing goods and services at the time of demonetization, lack of prior preparation, waiting in queues for exchanging old notes, and the quality service rendered by the banks. The coefficient of these covariates is $\delta, \zeta, \eta, \lambda, \sigma, \theta, \uparrow$, and $Ч$ respectively.

Table 1. Case processing summary statistics (Demographic Information)

\begin{tabular}{lcccccc}
\hline \multicolumn{7}{c}{ Panel A: Appropriateness of the Decision } \\
\hline Demonetization: & SD & D & N & A & SA & Total \\
\hline Frequency & 39 & 31 & 51 & 73 & 56 & 250 \\
$(\%):$ & $(15.6)$ & $(12.4)$ & $(20.4)$ & $(29.2)$ & $(22.4)$ & $(100.0)$ \\
\hline \multicolumn{7}{c}{ Panel B: Demographic Information } \\
\hline Demographic Information & \multicolumn{7}{c}{ Population of the respondents } \\
\hline Profile & \multicolumn{7}{c}{ Categories } & Frequency & Percentage \\
\hline
\end{tabular}




\begin{tabular}{|c|c|c|c|}
\hline & $25-30$ & 103 & 41.2 \\
\hline \multirow[t]{6}{*}{ Age } & $31-35$ & 58 & 23.2 \\
\hline & $36-40$ & 20 & 8.0 \\
\hline & $41-45$ & 36 & 14.4 \\
\hline & $46-50$ & 13 & 5.2 \\
\hline & 51 and Above & 20 & 8.0 \\
\hline & Total & 250 & 100.0 \\
\hline \multirow[t]{4}{*}{ Gender } & Male & 175 & 70.0 \\
\hline & Female & 75 & 30.0 \\
\hline & Total & 250 & 100.0 \\
\hline & Illiterate & 17 & 6.8 \\
\hline \multirow[t]{6}{*}{ Education } & Up to primary school & 23 & 9.2 \\
\hline & Up to $10^{\text {th }}$ standard school & 29 & 11.6 \\
\hline & Up to $12^{\text {th }}$ standard school & 64 & 25.6 \\
\hline & Undergraduate & 86 & 34.4 \\
\hline & Post-graduate & 31 & 12.4 \\
\hline & Total & 250 & 100.0 \\
\hline \multirow[t]{4}{*}{ Family size } & Join family & 115 & 46.0 \\
\hline & Nuclear family & 135 & 54.0 \\
\hline & Total & 250 & 100.0 \\
\hline & Daily wage earner & 40 & 16.0 \\
\hline \multirow[t]{5}{*}{ Occupation } & Agriculturalist & 18 & 7.2 \\
\hline & Shopkeeper & 46 & 18.4 \\
\hline & Small business & 37 & 14.8 \\
\hline & Others & 109 & 43.6 \\
\hline & Total & 250 & 100.0 \\
\hline
\end{tabular}

Source: Authors' Computation based on the questionnaire

The respondents' demographic profile is reported in table 01 based on Age, Gender, Education, Family size, and occupation. 103 respondents, representing 41.2 percent of the total respondents, are 25-30, followed by age group 31-35, representing 58 respondents and 23.2 percent of the total respondents. Similarly, the age group of 46-50 and above 51 represents 5.2 and 8.0 percent of the respondents. Likewise, the gender of the respondents is dominated by male and female, 175 respondents, and 70.0 percent are male, and 75 respondents and 30.0 percent are female. We have also asked about the respondents' education, family size, and occupation, represented in the table. Daily wage workers dominate the respondents' occupation, agriculturalist, shopkeeper, small business andothers' represent those who do not come under working class such as housewives (homemakers) jobless people who are a part of the unorganized labor class.

The necessary model fit condition has been checked using baseline comparison and tests the ordinal regression assumptions using a multi-collinearity test and parallel line test to assess the empirical approach's suitability. Multi-collinearity exists when the regression equation's independent variables are positively correlated with each other(Zikmund, 2010). Table 04 shows the tolerance level and the Variance Inflation Factors (VIF) for all the model variables. The VIF values $<1$ or $>10$ indicate that the variables are multi-collinear. The VIF between 1 and 10 in each casesuggests the absence of multi-collinearity(Gujarati \& Porter, 2009). The multi- 
collinearity in regression analysis refers to how strongly interrelated the model's independent variables are(Zikmund, 2010).

The other assumption relating to the ordinal regression is proportional odds, which specify the correlation among the response variable. The explanatory variable does not change for the response variable's categories. The parameter estimations do not change for cut-off points as well. In ordinal regression, the assumption of the proportional odds test observes the various categories' quality and resolves whether the assumption holds or not. Suppose the assumption does not fit, the interpretations about the results will be inaccurate(Erkan \& Yildiz, 2014). Researchers examine the test assumption with support of the full likelihood ratio test that compares the fitted location model to a model with varying location parameters(Laerd Statistics, 2013). The results of these tests are discussed in the below sections.

\section{RESULT \& DISCUSSION}

In the survey pertaining to the efficacy of the demonetization and the policy rollout on demonetizing old currencies from common public perspectives, most of the respondents favorthe policy rollout on demonetizing old currencies by the government. The summary of the survey findings shows that respondents considered the decision asappropriate. Concerning changes in the number of bank account holders' pre and post-demonetization, the result is depicted in the following table.

Table 2. Bank Account holders

\begin{tabular}{lccc}
\hline Bank account holder before demonetization & No & Yes & Total \\
\hline Frequency & 65 & 185 & 250 \\
Percentage & $(26 \%)$ & $(74 \%)$ & $(100.0)$ \\
\hline Bank account holder after demonetization & No & Yes & Total \\
\hline Frequency & 15 & 235 & 250 \\
Percentage & $(6 \%)$ & $(94 \%)$ & $(100.0)$ \\
\hline
\end{tabular}

Source: SPSS output

Table 2 reveals that the numbers of bank account holders among the respondents' pre and post-demonetization. Where 185 respondents are $74 \%$ of the study respondents, have a bank account before the demonetization. Likewise, the table shows that the number of bank account holders increased from 185 to 235 respondents, which is $94 \%$ of the study respondents. Therefore, the results of table 02 indicate that demonetization increased the number of bank account holders in India.

Authors measure the common public's opinions on the efficacy of the demonetization in controlling tax evasion, controlling black money, illegal investments, and regular business transactions. The following table 03 shows the views of the common public on the efficacy of demonetization.

Table 3. Opinions of Common Public on Demonetization

\section{Demonetization helps controlling tax} evasion

SD

D

A SA 


\begin{tabular}{lccccc}
$\begin{array}{l}\text { Frequency } \\
\text { Percentage }\end{array}$ & 22 & 38 & 75 & 84 & 31 \\
& $(8.8 \%)$ & $(15.2 \%)$ & $(30 \%)$ & $(33.6 \%)$ & $(12.4 \%)$ \\
\hline $\begin{array}{l}\text { Demonetisation helped control the } \\
\text { investment of Black money }\end{array}$ & SD & $\mathbf{D}$ & $\mathbf{N}$ & $\mathbf{A}$ & SA \\
\hline $\begin{array}{l}\text { Frequency } \\
\text { Percentage }\end{array}$ & 16 & 28 & 66 & 80 & 60 \\
\hline
\end{tabular}

\begin{tabular}{lccccc}
\hline $\begin{array}{l}\text { Demonetizationadversely affected } \\
\text { regular business transactions }\end{array}$ & SD & D & N & A & SA \\
\hline Frequency & 21 & 23 & 47 & 125 & 34 \\
Percentage & $(8.4 \%)$ & $(9.2 \%)$ & $(18.8 \%)$ & $(50 \%)$ & $(13.6 \%)$ \\
\hline
\end{tabular}

Note: Likert scale data tenets choice from 1-5, where 1 stands strongly disagree (SD), 2 stands for disagree (D), 3 stands for neutral (N), 4 stands for agree (A), and 5 stands for strongly agree (SA).

The results depict that the ordinary public hasperceived that India's demonetization policy was not effective in controlling tax evasion, illegal investments of black money. At the same time, $63.6 \%$ of the respondents agree and strongly agree that demonetization adversely affected India's regular business transactions.

In order to get a clear sign about the independent variable i.e. appropriateness of the demonetization decision by the government from the common man (general public) perspectives, researchers run ordinal regression analysis, the appropriateness of the government decision to demonetize the old currencies and introduce new currency, reflecting the insights and perceptions of common public as a response variable and the policy rollout on demonetizing old currencies measured via planning of money circulation at the time of demonetization, difficulties while purchasing goods and services, the timing of the demonetization, the time frame given to common public to demonetize their old currencies, lack of prior preparation, public awareness on objectives of the policy, waiting in lines to change the old coins, and the quality service rendered by the banks at the time of demonetization, represented in five-point Likert scale as a covariates laterally with age and occupation-based categorical variable.

Table 4. Test of Ordinal Regression Assumptions

\begin{tabular}{|c|c|c|c|c|c|c|c|c|}
\hline \multicolumn{9}{|c|}{ Panel A: Test of Multi-collinearity } \\
\hline $\begin{array}{l}\text { Variables } \\
\text { Collinearity } \\
\text { Statistics }\end{array}$ & $\begin{array}{l}\text { Money } \\
\text { Circula } \\
\quad \text { tion }\end{array}$ & $\begin{array}{l}\text { The } \\
\text { time } \\
\text { frame } \\
\text { has } \\
\text { given }\end{array}$ & $\begin{array}{c}\text { Public } \\
\text { awarene } \\
\text { ss on } \\
\text { Objectiv } \\
\text { es }\end{array}$ & $\begin{array}{c}\text { The right } \\
\text { time to } \\
\text { impleme } \\
n t \\
\text { Demon }\end{array}$ & $\begin{array}{l}\text { Lack of } \\
\text { prior } \\
\text { preparati } \\
\text { on }\end{array}$ & $\begin{array}{l}\text { problems } \\
\text { while } \\
\text { purchasi } \\
\text { ng goods }\end{array}$ & $\begin{array}{l}\text { Waiti } \\
\text { ng in } \\
\text { lines }\end{array}$ & $\begin{array}{c}\text { quality } \\
\text { services } \\
\text { rendere } \\
\text { d by } \\
\text { banks }\end{array}$ \\
\hline Tolerance & 0.561 & 0.671 & 0.699 & 0.471 & 0.591 & 0.486 & 0.630 & 0.778 \\
\hline VIF & 1.781 & 1.622 & 1.431 & 2.122 & 1.693 & 2.062 & 1.587 & 1.285 \\
\hline \multicolumn{9}{|c|}{ Panel B: Test of Parallel Lines } \\
\hline Model & & $-2 \log$ & ikelihood & Chi-Square & & df & & Sig. \\
\hline
\end{tabular}




\begin{tabular}{lllll}
\hline Null Hypothesis & 501.057 & & & \\
\hline General & $476.682^{\mathrm{b}}$ & $24.375^{\mathrm{c}}$ & 51 & 0.999 \\
\hline
\end{tabular}

\section{Source: SPSS output}

The model diagnostic statistics results have been reported in table 04 to understand whether the ordinal regression model used in the study satisfies all pre-conditions/assumptions. A Multi-collinearity test that checks forthe high degree of correlation between the explanatory variables specifies that the study's model is free from multi-collinearity issues as the VIF values areless than 10 . Tolerance values are greater than 0.10 for all the explanatory variables.

The ordinal regression models used in the study are based on the fundamental assumption of proportional odds that highlights an identical effect is observed from each explanatory variable at each cumulative split of ordinal response variables(Laerd Statistics, 2013). Theparallel line test is used to prove whether the model used in this study satisfies the proportional odds assumption (see table 04, panel B). The parallel lines test result shows an insignificant probability value at a $5 \%$ level of significance. We failed to reject the test state's null hypothesis that the location parameters (i.e., slop coefficients) are the same across response categories. This indicates that the model used here also satisfies the assumption of proportional odds.

Before discussing the ordinal regression estimates, the researchers verified the goodness of fit by comparing the baseline model with the model used. The significance of the (McCullagh \& Nelder, 1989) chi-square value depicts that the model used here indicates better prediction than the simple intercept-only (baseline) model, which is similar to making a guess based on the marginal probabilities for the outcome categories\{Citation\}(Elamir \& Sadeq, 2010). The following table, 04 , shows a summary of model fitting.

Table 4. Overall Model Fitting Information

\begin{tabular}{lllll}
\hline \multicolumn{4}{c}{ Model Fitting Information } \\
\hline Model & $\begin{array}{l}\text {-2 Log } \\
\text { Likelihood }\end{array}$ & $\begin{array}{l}\text { Chi- } \\
\text { Square }\end{array}$ & df & Sig. \\
\hline Intercept Only & 774.581 & & & \\
Final & 501.057 & 273.525 & 17 & 0.000 \\
\hline
\end{tabular}

Source: SPSS output

After conducting the diagnostic check and model fit verification, the researchers further discuss the ordinal regression results. The following table, 05 , reveals the estimates of ordinal regression parameters.

Table 5. Estimates of Ordinal Regression Parameters

\begin{tabular}{|l|c|c|c|c|l|l|l|}
\hline Variables & $\begin{array}{c}\text { Coefficient } \\
\text { Notation }\end{array}$ & Estimate & Std. Error & Wald & Sig. & Odds Ratio \\
\hline Constant $[\mathrm{SD}]$ & & $\alpha 1$ & 3.296 & 0.909 & 13.142 & $0.000^{* * *}$ & 27.005102 \\
\hline Constant $[\mathrm{D}]$ & $\alpha 2$ & 4.839 & 0.938 & 26.629 & $0.000^{* * *}$ & 126.31409 \\
\hline
\end{tabular}




\begin{tabular}{|c|c|c|c|c|c|c|}
\hline Constant $[\mathrm{N}]$ & $\alpha 3$ & 6.978 & 1.011 & 47.638 & $0.000 * * *$ & 1073.2446 \\
\hline Constant $[\mathrm{A}]$ & $\alpha 4$ & 9.751 & 1.101 & 78.387 & $0.000 * * *$ & 17163.848 \\
\hline Money Circulation & $\delta$ & 0.581 & 0.150 & 15.082 & $0.000 * * *$ & 1.7875468 \\
\hline Lack of Prior preparation & $\zeta$ & -0.063 & 0.138 & 0.205 & 0.651 & 0.9392421 \\
\hline $\begin{array}{l}\text { Problem while Purchasing } \\
\text { goods }\end{array}$ & $\eta$ & -0.380 & 0.145 & 6.826 & $0.009 * *$ & 0.6840535 \\
\hline Public awareness on objectives & $\lambda$ & 0.080 & 0.139 & 0.329 & 0.566 & 1.0830595 \\
\hline Time frame given & 6 & 0.330 & 0.128 & 6.680 & $0.010 * *$ & 1.3907601 \\
\hline Waiting in lines & $\theta$ & 0.089 & 0.146 & 0.372 & 0.542 & 1.0932785 \\
\hline Quality services rendered & q & -0.060 & 0.136 & 0.196 & 0.658 & 0.9417167 \\
\hline $\begin{array}{l}\text { The right time to implement } \\
\text { demonetization }\end{array}$ & Ч & 1.512 & 0.181 & 70.007 & $0.000 * * *$ & 4.5372563 \\
\hline \multicolumn{7}{|l|}{ Age group } \\
\hline A. $[25-30]$ & $\beta_{1}$ & 0.733 & 0.518 & 1.998 & $0.058 *$ & 2.0802892 \\
\hline B. [31-35] & $\beta_{2}$ & 0.797 & 0.544 & 2.143 & $0.043 *$ & 2.2184108 \\
\hline C. $[36-40]$ & $\beta_{3}$ & 0.495 & 0.667 & 0.551 & 0.458 & 1.6404722 \\
\hline D. [41-45] & $\beta_{4}$ & -0.075 & 0.589 & 0.016 & 0.898 & 0.9273929 \\
\hline E. $[46-50]$ & $\beta_{5}$ & 0.391 & 0.722 & 0.294 & 0.588 & 1.4787684 \\
\hline F. $[50$ \& Above $]$ & ß6 & $0^{\mathrm{a}}$ & & & & \\
\hline \multicolumn{7}{|l|}{ Occupation group } \\
\hline [Daily wage workers] & $\Upsilon_{1}$ & 0.251 & 0.396 & 0.403 & 0.526 & 1.2855481 \\
\hline [Agriculturalists] & $\Upsilon_{2}$ & 0.043 & 0.554 & 0.006 & 0.938 & 1.043906 \\
\hline [Shopkeepers] & $\Upsilon_{3}$ & -0.576 & 0.383 & 2.262 & 0.133 & 0.5620558 \\
\hline [Small Business holders] & $\Upsilon_{4}$ & -0.023 & 0.404 & 0.003 & 0.955 & 0.9773644 \\
\hline [Others] & $\Upsilon_{5}$ & $0^{\mathrm{a}}$ & & & & \\
\hline
\end{tabular}

Source: SPSS output. Note: *indicate values significant at $5 \%$ level ** indicate values significant at $1 \%$ level

Table 5 shows the results of the estimate of ordinal regression parameters, among the covariates used to capture the influence on the response variable, the variables relating to the planning of money circulation, difficulties while purchasing goods and services, the time frame of the demonetization by the government, and the time frame given to the common public to demonetize their old currencies are turned to be statistically significant. And the variables such as lack of prior preparation, public awareness on objectives of the policy, waiting in lines to change the old currencies, and the quality service rendered by the banks at the time of demonetization are not statistically significant.

The variable that shows the planning of money circulation at the time of demonetization indicates that a unit increase in the value of the variable will increase odds in favor of the response on the appropriateness of the decision to demonetize the old currency and introduce the new money over the answer against the demonetization decision are more significant than 1.7875468, times. Likewise, the odds of getting a response in favor of the decision to demonetize old currency are greater if respondents are in prefer, positive response relating to the reactions on difficulties while purchasing goods and services, the time frame of the demonetization by the government, and the time frame given to the common public to demonetize their old currencies as indicated by higher odds ratio relating to these variables. 
In the categorical variables age- groups, the results show that there is more possibility that respondents in the age group (25-30), (31-40) the youngster and middle-aged individuals are more likely in favor of positive response toward the decision to demonetize old currency and introduction new currency to the economy, compared to the veterans, the statistically significant values for the age group (25-30) and (31-40) reveals that the odds are firmly in favor of the decision is 2.0802892, and 2.2184108, times greater than the veterans as shows by cumulative odds ratio values.

Likewise, in the case of the occupational group, the result indicates that there is a possibility that the respondents in daily wage workers and agriculturalists are more likely in favor of the demonetization decision compare to the group's shopkeepers, small business holders, and group others that represent the people from unorganized sectors. The daily wage workers' statistical values indicate that the odds are firmly in favor of the demonetization decision is 1.2855481 , and 1.043906 times greater than the other class of people, due to the cumulative odds ratio.

\section{FINDINGS \& CONCLUSION}

The study explores the efficacy of demonetization from India's common public perspectives, the policy implemented by India's government to fight against black money, drying the financial roots of terrorism, and direct the civilization towards digital transactions anda cashless economy. The study's main purpose is to study if the policy implementation was effective, study the public's opinions on policy reactions, and understand their hardships due to policy implementation. The descriptive statistics results suggest that the demonetization increased the numbers of bank account holders in India. There is not much impact of demonetization on controlling evasion of tax and illegal investments of black money, and the policy adversely affects regular business in the country. The ordinal regression findings reveal that the ordinary public, despite facing enormous challenges while purchasing goods and services at the time of demonetization, consider that demonetization implementation was a practical step in directing the civilization towards the digital transaction and cashless economy, the results obtained from the ordinal regression analysis also depicts that the government implemented the policy at the right time, the government well planned the money circulation at the time of demonetization, the time frame given to the public wassufficient enough to change their old notes. Before demonetization, there was a proper system in place, and the general public has not faced any problems. The otherwise innocent common public was harassed and disturbed to their day-to-day transactions and withdrawn their complex and earned money in the name of controlling black money, terrorism, and fake currency circulation should not be punished to the common public.

\section{REFERENCES}

Beg, S., \& Joshi, N. (2017). Public Perception of the Impact of Demonetization in India: An Empirical Study. Journal of Commerce \& Trade, 12(2). https://doi.org/10.26703/JCT.v12i2-11

Briceno, A. J. H., \& de Hurtado, S. Z. (2019). India-Venezuela: Analysis of Demonetization Measures. International Journal of Advances in Management and Economics, 8(2), 11.

Chodorow-Reich, G., Gopinath, G., Mishra, P., \& Narayanan, A. (2020). Cash and the Economy: Evidence from India's Demonetization. The Quarterly Journal of Economics, 135(1), 57103. https://doi.org/10.1093/qje/qjz027 
Chowdhury, M. H., \& Hosain, M. S. (2018). Demonetization Policy: The Indian Debate. Asian Journal of Research. https://doi.org/10.26739/2433-202x

Dash, A. (2017). A Study on Socio-Economic Effect of Demonetization in India. International Journal of Management and Applied Science,3(3), 4.Retrieved from http://iraj.in/journal/journal_file/journal_pdf/14-349-149485006913-15.pdf

Deepak Chawla \& Neena Sondhi. (2015). Research Methodology Concepts and Cases (Second Edition). VIKAS® PUBLISHING HOUSE PVT LTD.

Elamir, E., \& Sadeq, H. (2010). Ordinal Regression to Analyze Employees' Attitudes towards the Application of Total Quality Management. Journal of Applied Quantitative Method, 5(3), 12.Retrieved from http://www.jaqm.ro/issues/volume-5,issue4/pdfs/10_elamir_sadiq.pdf

Erkan, ARI \& Yildiz, Zeki. (2014). Parallel Lines Assumption in Ordinal Regression and Analysis Approaches. International Interdisciplinary Journal of Scientific Research, 1(3), 8-23.Retrieved from https://iijsr.org/data/frontImages/gallery/Vol._1_No._3/2._823.pdf.

Ghandy, K. (2016). One Step Forward, Two Steps Back. Economic \& Political Weekly, 50, 3.Retrieved from https://www.epw.in/journal/2016/50/commentary/demonetisation.html

Ghosh, J., Chandrasekhar, C. P., \& Patnaik, P. (2017). Demonetisation Decoded: A Critique of India's Currency Experiment (1st ed.). Routledge India. https://doi.org/10.4324/9781315160979

Gujarati, D. N., \& Porter, D. C. (2009). Basic econometrics (5th ed). McGraw-Hill Irwin.

Khiaonarong, T., \& Humphrey, D. (2019). Cash Use Across Countries and the Demand for Central Bank Digital Currency. IMF Working Papers, 19(46), 1. https://doi.org/10.5089/9781484399606.001

Koshy, L. (2017). Influence of Demonetisation on Unorganised Retailers. SSRN Electronic Journal. http://dx.doi.org/10.2139/ssrn.2969784

Kumar, D. R. (2011). Research Methodology a step-by-stepguide for the beginner. SAGE Publications India Pvt Ltd B 1/I1 Mohan Cooperative Industrial Area Mathura Road New Delhi 11004, 366.

Kumar, P. (2017). Demonetization and its impact on the adoption of digital payment: opportunities, issues, and challenges. Abhinav National Monthly Refereed Journal of Research in Commerce \& Management, 6(6), 15.

Laerd Statistics. (2013). https://statistics.laerd.com/spss-tutorials/ordinal-regression-using-spssstatistics-3.php. Retrieved May 19, 2019, from statistics.laerd.com: https://statistics.laerd.com/premium/index.php 
Lal, B. S. (2018). Political Economy of Demonetization in India: Issues and Impact. The Indian Economic Journal: The Quarterly Journal of the Indian Economic Association, I, 82.

M C VAISh. (2005). Monetary Theory (Sixteenth Edition). VIKAS® PUBLISHING HOUSE PVT LTD.

Mahajan, P., \& Singla, A. (2017). Effect of demonetization on financial inclusion in India. International Journal of Science Technology and Management, 6(1), 6.

Massi, M., Sullivan, G., Strauß, M., \& Khan, M. (2019). How Cashless Payments Help Economies Grow. 14.

McCullagh \& J. A. Nelder. (1989). Generalized Linear Models (Second Edition). Champman and Hall. http://utstat.toronto.edu/ brunner/oldclass/2201s11/readings/glmbook.pdf

McLeay, M., \& Radia, A. (2014). Money in the modern economy: An introduction1. 10.

Mishra, D. (2017). Demonetization: It's Socio-Economic Impact. International Journal For Innovative Research in Multidisciplinary Field, 3(4), 4.

Mohan, R., \& Ray, P. (2019). Indian Monetary Policy in the Time of Inflation Targeting and Demonetization: Indian Monetary Policy. Asian Economic Policy Review, 14(1), 67-92. https://doi.org/10.1111/aepr.12242

Mohindra, K. S., \& Mukherjee, S. (2018). Can Short-term Economic Policies Hurt the Health of the Poor? Demonetization in India. International Journal of Health Services, 48(3), 482494. https://doi.org/10.1177/0020731418772465

Panah, A. M., \& Muniraju, Y. (2020). Demonetization Related Factors in India: An Exploratory Study on Perceptions and Opinions of Common Man. International Journal of Innovation and Research in Educational Sciences, 7(5),13.Retrieved from http://ijires.org/administrator/components/com_jresearch/files/publications/IJIRES_1781 _FINAL.pdf

Paul van der Knaap, Vries, T. de, \& Ewout Boesenach. (2018). World Cash reportl (p. 196).Retrieved from https://cashessentials.org/app/uploads/2018/07/2018-world-cashreport.pdf

Samuel, Y., \& Saxena, A. K. (2017). A Study On Demonetisation And Its Impact On Indian Economy. International Journal of Innovative Research and Advanced Studies, 4(2), 4.Retrieved from http://www.ijiras.com/2017/Vol_4-Issue_2/paper_64.pdf

Sharma, C. (2019). Estimating the size of the black economy: New evidence from India. International Journal of Emerging Markets, 14(2), 300-321. https://doi.org/10.1108/IJoEM-01-2018-0034

Singh, C. (2018). India Since Demonetisation. SSRN Electronic Journal. https://doi.org/10.2139/ssrn.3151238 
Sivathanu, B. (2019). Adoption of digital payment systems in the era of demonetization in India: An empirical study. Journal of Science and Technology Policy Management, 10(1), 143171. Retrieved from https://doi.org/10.1108/JSTPM-07-2017-0033

Vij, D. D. (2018). Demonetization: Effects on Indian Economy. International Research Journal of Business and Management- IRJBM, Volume No-XI(Issue-1), 11.

Zikmund, W. G. (2010). Business research methods. South-Western Cengage Learning.

\section{Copyrights}

Copyright for this article is retained by the author(s), with first publication rights granted to the journal. This is an open-access article distributed under the terms and conditions of the Creative Commons Attribution license (http://creativecommons.org/licenses/by/4.0/) 